\title{
Managing After a Disaster: Or There and Back Again
}

\author{
James G. Milles
}

\begin{abstract}
The library literature is full of articles and books on disaster preparedness, from evacuation of staff and users to salvaging books and equipment. Little guidance is available, however, on dealing with management issues such as staff morale and user frustration. If handled successfully, the inevitable disruption can provide opportunities for staff growth. Attention to issues of morale and staff cohesiveness is essential to providing the level of service that users expect. [Article copies available for a fee from The Haworth Document Delivery Service: 1-800-HAWORTH. E-mail address: <docdelivery@haworthpress.com> Website: <http://www.HaworthPress.com> () 2006 by The Haworth Press, Inc. All rights reserved.]
\end{abstract}

KEYWORDS. Disaster preparedness, law library administration, preservation

\section{THE FELLOWSHIP OF THE RING}

On the morning of Saturday, March 19, 2005, a fire of unidentified origin was discovered in a dining and vending machine area in the northeast corner of the second floor of O'Brian Hall, the home of the Law School at the University at Buffalo. Several local fire departments responded quickly, and the fire was extinguished before the building suffered major structural damage. Between the fire and the water dam-

James G. Milles is Associate Dean for Legal Information Services/Director of the Law Library/Associate Professor of Law, University at Buffalo Law School Library.

Legal Reference Services Quarterly, Vol. 25(1) 2006

Available online at http://www.haworthpress.com/web/LRSQ

(c) 2006 by The Haworth Press, Inc. All rights reserved.

doi:10.1300/J113v25n01_04 
age, however, several classrooms, a student lounge on the second floor, and a lecture hall on the first floor directly below the fire-the Law School's largest lecture hall-were rendered unusable for the rest of the semester.

The Law Library occupies the upper six floors of O'Brian Hall, forming an atrium or "ring" around an open space broken only by a ceiling at the level of the fourth floor. The site of the fire opened into a hallway running along the north side of the Law Library. On that side of the Law Library is the main staff area of the Law Library, including the administrative offices, Cataloging and Acquisitions departments, and the Reference Desk. On the south side of the same floor is the Access Services department, housing Circulation, Reserve, and Interlibrary Loan. The second floor of O'Brian Hall houses the entrance and reading room for the Law Library, with a third-floor mezzanine level and a high ceiling extending to the fourth floor. This open space acted as a chimney, as the hot air forced the smoke through the plenum between the second and third floors into the Law Library's reading room. The air handling system further circulated the smoke through the upper floors of the Law Library, all the way to the seventh floor. None of the books in the collection were destroyed, but the smoke left a dense layer of soot on everything on the second and third floors of the Law Library, with somewhat less soot on floors four through six, until the smoke trapped on the seventh floor left another heavy deposit of soot on the top floor.

The University response was swift and well organized. Hours after the fire was extinguished, over two dozen representatives from the Provost's office, campus security, plant and maintenance, occupational safety and health, network services, the University Libraries, outside contractors, and more gathered for the first of what became a regular series of meetings. The University Libraries had developed a Disaster Prevention, Recovery, and Response Manual some years earlier, ${ }^{1}$ but it had never been put to the test. The University had some experience with smaller fires on campus, but nothing to compare with the O'Brian Hall situation. Nonetheless, the University was able to mobilize a coordinated response almost immediately; at the first meeting, it was clear that people already knew what they had to do and in many instances had already started doing it.

The classrooms on the second floor were used primarily by the University, not the Law School. Several of the large classes that met in the first-floor lecture hall had to be relocated to other classrooms in O'Brian; a handful of classes, including Advanced Legal Research, were relocated to nearby buildings. Two or three administrative offices on the 
third floor, directly above the fire, were vacated for several weeks because of heat damage to electrical wiring. All classes were cancelled on the first two days after the fire, but the full schedule of classes was back online by Wednesday morning.

The lengthy process of remediation and repair began almost immediately. Under the direction of University Facilities, in consultation with the Law School and Law Library, teams of contractors-carpenters, electricians, cleaners, and so on-began the necessary reconstruction. It soon became clear that the remediation would consist of two elements: cleanup and repair of destruction immediately caused by the fire, and asbestos abatement made necessary because the fire and its aftermath exposed pre-existing asbestos containing material, or ACM.

Asbestos is a general term for several different fibrous minerals widely used in construction and manufacturing from the early 1900s to the 1970s for its fire retardant and insulating properties. ${ }^{2}$ When subsequent research demonstrated a link between asbestos exposure and health risks such as lung cancer, mesothelioma, and asbestosis, it became heavily regulated and is rarely used today except in highly specialized applications. As long as asbestos-containing material remains intact and undisturbed, it does not pose a health risk, but damage or deterioration can cause ACM to release fibers into the air, where they can be inhaled. O'Brian Hall opened in 1973, toward the end of the period when asbestos insulation was widely used in construction. It was well known that asbestos was used in some areas of the building. A quarterly schedule of testing by the University Office of Environment, Health and Safety, instituted several years ago, monitored the quality of the air to ensure that there was no risk of asbestos exposure.

The fire suddenly made asbestos abatement essential. In the areas closest to the fire, ceiling panels were torn down in the process of extinguishing the fire. Water seeping into the lecture hall below damaged the $\mathrm{ACM}$ and required its removal. In the hallway between the classrooms and the library, and in the staff areas of the library, soot deposits in the plenum had to be cleaned, again disturbing the ACM and requiring abatement. The result was that the library, which had escaped direct fire damage, became a construction site until the end of the semester. While Law School classes proceeded with only a brief interruption, the Law Library faced a shutdown for the second half of the semester.

Thus, armed only with their dedication, and not knowing the challenges that lay ahead, our brave fellows set forth to provide library services as best they could. 


\section{THE TWO TOWERS}

Since the Law Library is considered a part of the University Libraries system, and thus had a strong pre-existing relationship with the other libraries, there was no question but that the University Libraries would assist us in providing temporary accommodations. Reference, Access Services, Acquisitions and Cataloging moved to Lockwood Library, located literally just down the hall. (Because of the infamous Buffalo winters, most of the buildings at UB are connected. One can easily walk from one library to another without going outdoors.) Audiovisual Services stayed in O'Brian Hall, so they could continue to deliver equipment to classrooms. As director, I also stayed in O'Brian Hall, in order to keep in close contact with the Law School and with progress in the reconstruction of the Law Library. Both Audiovisual Services and I moved out of the Law Library into temporary space in the Judge's Chambers, which was vacant at the time. Several weeks later, when we were forced to vacate the Judge's Chambers for court sessions, we were able to move into conference rooms on the fifth floor.

Considering the extent of the damage to the Law Library, work proceeded quickly. The first task facing the Law Library staff was to pack up and move everything from our workspaces that we expected to need for the next couple of months. Anything we did not take with us immediately was to be packed and stored in rented trailers parked outside the Law School, where it would be inaccessible until we moved back in. Accordingly, Law Library staff spent several days in jeans and sweatshirts, some of them wearing filter masks to avoid inhaling soot, cleaning and packing books, files, papers, and office supplies, and packing them into boxes labeled either for immediate moving or for storage.

The University quickly decided that sufficient funding would be provided to restore the Law School and Law Library to their previous condition, but that in most cases improvements would not be funded. The latest estimates of the cost are around $\$ 2$ million, with the funding coming from a combination of special allocation from the State University of New York and internal reallocation of UB capital funds.

The hardest hit were the second and third floors, where every bookover 110,000 volumes-had to be individually removed and cleaned by hand. Enviro-Care Inc., a local company with expertise in disaster restoration services, was awarded the contract for the cleaning. The cover of each book was sprayed with a diluted ionizing solution and wiped dry; the edges of the text block were wiped with a chemically treated smoke 
cleaning sponge. Over a dozen workers completed this job in only a few weeks. In addition, ceiling panels were torn down throughout the library workspace on the north side of the Law Library to allow for encapsulation of the asbestos in situ. On the upper floors, where there was less soot, it was sufficient to thoroughly vacuum all shelves and books with HEPA vacuums.

All carpeting on floors three through seven, and every piece of upholstered furniture, were shampooed. The walls on floors two and three were cleaned, sealed (to encapsulate any remaining soot odor), and painted. The carpeting on the second floor was removed and replaced. Where Ethernet wiring had to be replaced, existing Category 3 wiring was upgraded to Category 5. Our request to install additional circuits in some areas where electrical wiring needed to be replaced was denied as out of the scope of the restoration project.

With the rebuilding and repair underway, and with the assurance that the costs would be covered, my most immediate challenges were: how to maintain good morale and a sense of cohesiveness among a staff divided between two different buildings; and how to assure that service to students and faculty was as seamless as possible. The second goal was directly related to the first. With the 10 faculty librarians, 9 paraprofessional staff, and two to three dozen student assistants divided and resettled awkwardly in temporary locations sharing cramped quarters, I was concerned that nerves could easily fray. Physical distance and lack of contact could lead to misunderstandings and tensions. It was obvious that keeping the staff unified was essential to providing an excellent level of service.

The first few days after the fire, the Law School and Law Library were closed. On the morning of Tuesday, March 22, three days after the fire, a full staff meeting was held for all Law Library personnel. I explained what little was known of the fire, and that arrangements were being made to find temporary space for them in Lockwood Library. Several offices and workstations were made available, and staff members decided among themselves who would go where. At that meeting we decided to have a regular "lunch date" at noon each day at the University cafeteria. Staff were invited, but not required, to attend. This gave us all a chance to check in with each other, receive progress reports, and discuss and make decisions. The first few weeks a dozen or more people showed up each day; gradually attendance dwindled somewhat, but the daily lunches continued with a rotating cast of attendees until we moved back into the Law Library. 
Several staff had to share telephones, so we purchased several inexpensive two-way radios and distributed them in the various departments. With rare exceptions, I visited staff members in each of their various locations every day.

Each department brought with them the materials they would need to continue to provide services to our users. The Circulation and Reserve staff moved the reserve collection and files to the Circulation desk at Lockwood Library. Most old exam files have been digitized and were accessible to UB law students through a web server; this proved exceptionally helpful as the end of the semester approached and students could access the materials most in demand from their homes. The Reference librarians moved a core collection of hard copy materials to the Business Documents section of Lockwood Library, which had been designated the temporary Law Library Reference Desk. Acquisitions and Cataloging staff brought book trucks full of material to Central Technical Services (CTS) in Lockwood Library. Mail delivery was redirected so that materials receiving and processing could proceed in CTS without interruption.

Since the area of the library affected by the asbestos abatement was contained and did not include the library stacks, our exile staff members were able to enter the building to retrieve books for patrons on demand. This gave us an unanticipated opportunity to sample how much of the collection was not duplicated online. The statistics on items retrieved are shown below in Figure 1. Although the distribution of types of materials shows that more than twice as many monographs were requested as all other materials put together. This is not surprising since almost the entire core of the collection-the primary federal and state materials, digests, law reviews, legal encyclopedias, formbooks, and treatises on the second and third floors-is accessible on WESTLAW and LexisNexis. However, the pattern of users was illuminating. Out of 333 items requested, law faculty requested only 14, and JD students requested only 45. Fifty-one items were retrieved for LLM students, but by far the largest number of retrieval requests was 84 for non-law students. ${ }^{3}$

As anyone knows who has seen the inflatable moose head on the wall of my office, I believe in a sense of humor in the workplace. I used the Internet shop Cafepress.com to design and purchase several dozen "UB Law Library in Exile" buttons, which I distributed to all staff members. ${ }^{4}$ The staff enjoyed this show of solidarity, and wore the buttons regularly. The buttons turned out to be practical as well, identifying Law Library staff at the Lockwood Circulation and Business Documents Reference desks. In fact, the buttons became sought-after 
FIGURE 1. Items Retrieved by Type and Patron Class

$\begin{array}{lcccccccc} & \begin{array}{c}\text { Law } \\ \text { Faculty/Staff }\end{array} & \begin{array}{c}\text { Law } \\ \text { Students }\end{array} & \text { LLM } & \begin{array}{c}\text { Other } \\ \text { Faculty }\end{array} & \begin{array}{c}\text { Other } \\ \text { Students }\end{array} & \text { Courtesy } & \text { Hein } & \text { Total } \\ \text { Monographs } & 5 & 27 & 51 & 4 & 84 & 10 & 1 & 182 \\ \text { Serials } & 1 & 3 & 9 & 0 & 8 & 5 & 37 & 63 \\ \text { Statutory } & 5 & 1 & 20 & 0 & 2 & 0 & 0 & 28 \\ \text { Law Reviews } & 2 & 1 & 6 & 0 & 2 & 0 & 11 & 22 \\ \text { Looseleafs } & 1 & 11 & 3 & 0 & 0 & 2 & 0 & 17 \\ \text { Audio-Visual } & 0 & 2 & 0 & 3 & 1 & 1 & 0 & 7 \\ \text { Reporters } & 0 & 0 & 2 & 0 & 0 & 5 & 0 & 7 \\ \text { United Nations } & 0 & 0 & 4 & 0 & 0 & 0 & 0 & 4 \\ \text { Administrative } & 0 & 0 & 2 & 0 & 0 & 0 & 0 & 2 \\ \text { Encyclopedias } & 0 & 0 & 0 & 0 & 1 & 0 & 0 & 1 \\ \text { Total } & 14 & 45 & 97 & 7 & 98 & 23 & 49 & 333\end{array}$

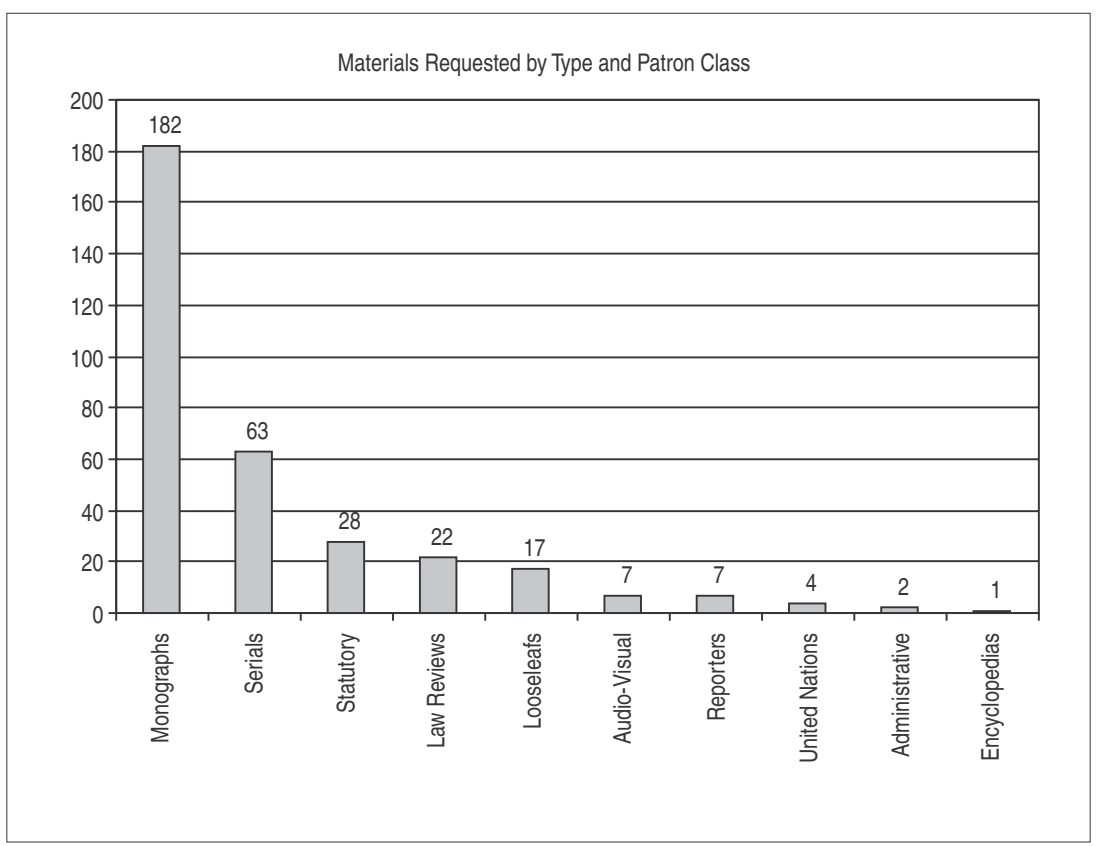


collector's items: several of the contractors, staff from University Facilities, and other librarians asked for their own "UB Law Library in Exile" buttons.

One unique logistical problem was presented by the Law Library's passport service. ${ }^{5}$ Since the summer of 2004, the Law Library has been a certified Passport Acceptance Facility. University students, faculty, and staff, and even members of the public appreciate the service and are happy to pay an additional fee for the convenience and the personal attention they receive from the Law Library Acquisitions staff, who are authorized to distribute forms, accept completed paperwork, review required documentation and forward applications to the U.S. regional passport agency. Demand for this service did not let up after the fire. We continued to receive a steady flow of passport applicants, and arrangements had to be made to serve them.

In the Law Library, the Acquisitions Department is centrally located just a few steps from the Reference Desk. In Lockwood Library, they were located on separate floors, and the Acquisitions staff work area was inaccessible to the public. Accordingly, we set up a passport office near the temporary Law Library Reference desk, complete with space for the full set of forms and instruction and a passport camera. Passport applicants were directed to the Reference Desk, where the staff phoned-or, if necessary, used the two-way radios-to call the Acquisitions staff. It was a clumsy system, but we managed.

Law Library staff members were deployed to be as accessible as possible to the law students on a face-to-face basis. At the same time, we used technology to provide more information. Because the destruction in the library was not immediately obvious to the users-we recognized that it was essential to keep students and faculty informed of what was going on. Soot damage was everywhere, but the building was still standing, and from the outside one might be unaware of the damage within the Law Library's walls. Law schools are notorious rumor mills, and we decided that the best way to keep students on our side was to keep them informed of our daily progress-and, most importantly, when they would be able to return. The obvious answer: start a blog. ${ }^{6}$

I had been interested in blogging technology for some time. ${ }^{7}$ In fact, I had started my first blog just two weeks before the fire. This experience proved handy, as I set up a new blog using the same free and widely used blogging service, Blogger (http://www.blogger.com). In only a few minutes I selected a design and established policies (for example, I chose to allow anonymous postings). Two days after the fire, "UB Law Library In Exile" appeared at http://ublawlib.blogspot.com. ${ }^{8}$ 
Unlike a listserv, a blog does not force information on unwilling readers; interested readers go to the blog to read it. Many also allow readers to comment, often anonymously; and many include a "trackback" function that notifies the author of the blog whenever another blogger links to a post on his or her blog. These features made a blog an ideal medium for providing progress reports on the Law Library's recovery to those students and faculty who were concerned, without filling up their email boxes with unwanted messages. In a large-scale disaster, managing the media can be a crucial element of the recovery. ${ }^{9}$ In our case, the blog enabled us to self-publish, and to get our message out to our patrons without a media filter.

For the first few days, reports were posted several times a day. Postings included lists of quiet study spaces in the University Libraries, temporary office and telephone numbers for library staff, frequent descriptions of the work as it proceeded, and pictures recording the devastation and the gradual cleanup and repair.

Unfortunately, since I was so new to blogging, I was learning as I went along. The free Blogger.com system does not include hit tracking, which is available from several third-party services. For that reason I have no statistics of how many users were viewing the blog in its crucial first few weeks. Similarly, it is impossible to say how much the blog contributed to the positive attitude of the students. Nonetheless, I believe that the blog played an important role in keeping the students informed and reassured, and in enlisting them in our support. It was striking how generous and patient they were. When I asked students how they were managing with the Law Library out of commission, they frequently noted how they were looking forward to returning to their usual study spaces, and how they did not miss the Library until it was gone. On more than one occasion students expressed concern for us or asked how we were managing with the disruption of our offices.

The Law Library's main services-Circulation, Reserve, Reference, Acquisitions, Cataloging, and Audiovisual-were quickly up and running in its two locations. The Administrative office remained in close contact with the Dean's Office and the law students in O'Brian Hall. The one service over which we had little control was printing.

The Law School provides students with unlimited free printing in three computer labs, located on the third, fifth, and sixth floors of the Law Library, but administered by the Law School's Information Technology department. ${ }^{10}$ The extensive infiltration of soot into the equipment created its own risk of fire. All computers and printers (including the stand-alone LexisNexis and WESTLAW printers) had to be cleaned 
before they could be turned on again; some of the printers eventually proved unrecoverable. The extended shutdown of the labs meant that many law students were confronted for the first time with the hourslong print queues at the University Libraries computer labs. These print queues were made worse by the sudden influx of over 700 law students who had not previously used the University Libraries computers. ${ }^{11}$

Solving the printing problem was the most challenging situation we faced, and it tested the patience of staff and administrators in both the Law Library and Law IT. Once or twice tempers flared. However, both sides agreed that the fifth and sixth floors of the Law Library should receive priority in the effort to reopen. The largest and most heavily used computer lab, with 18 computers, was on the third floor, but because of the heavy smoke damage that area required the greatest amount of work. ${ }^{12}$ The fifth floor, which houses the Audiovisual Department with its own circulation desk, as well as an unused space (formerly a faculty library) that seemed suitable as a temporary home for Reference, Cataloging, and Acquisitions, as well as a second computer lab, was identified as the first floor to reopen. A third lab is located on the sixth floor, as is an emergency exit that we were able to convert to card swipe access for temporary use as the main entrance during the interim. The computers from the third floor lab, were cleaned and moved temporarily to the sixth floor. This took time, and in the interim, extraordinary measures were put into place to provide printing. The Lexis representative arranged to route Lexis print jobs to the journal offices, picked them up each day, and delivered them to the Law Library staff at the Circulation desk in Lockwood Library; a student representative with Westlaw did the same. Remarkably, all but one or two computers were eventually cleaned and successfully put back in use.

\section{THE RETURN OF THE KING}

On Wednesday, April 13, floors four through seven reopened. As we began to reoccupy the Law Library, we quickly realized that we would have to manage our resources by focusing on our primary users. As a state university with a long-standing commitment to public service, we have always been open to and welcoming of our non-law users, including other UB students and faculty, students and faculty from other institutions, members of the bar, and the general public. With the first two floors still closed, however, our two largest reading areas were unavailable, and we could not afford to have the remaining seats occupied by 
undergraduates seeking a quiet place to study. With a swipe card lock installed on the sixth floor door, we were able to limit access to law students. Still, we did not entirely exclude other law library users. We posted a notice on our website, and a message on our voice mail, that the Law Library was open by appointment to other users requiring access to legal materials.

To mark the partial reopening, I announced a "Rename the Blog" contest.

The Law Library has come back from exile and (partially) reopened, and services are now being provided back home in O'Brian Hall. As we make the transition back to full services in our newly cleaned, carpeted, and lighted facility, it is time both to rename this blog and to redefine its purpose. We will continue to use this medium as a way of publicizing Law Library news and services (such as the upcoming Legal Research Refresher Clinics to help you prepare for your summer jobs), and will continue to welcome your comments. So what should we call it? We are asking for your help. All law students, faculty and staff are invited to enter the "Rename the Blog" contest. Each entrant will receive a collectible "UB Law Library in Exile" lapel button. The entrant whose submission best captures the Law Library's spirit of service and its role in the 21 st century law school will receive a rare "UB Law Library in Exile" commemorative coffee mug, crafted from hefty 15 -oz. ceramic. ${ }^{13}$

Over a dozen students and staff members responded, and four submitted some version of "Phoenix," for the mythical bird that is eternally reborn from its own ashes. I eventually settled on "UBLaw Phoenix" for the new name, and each of the four received a coffee mug.

Meanwhile, work continued on the second and third floors. Carpeting was torn up and replaced. Books were cleaned by hand. Furniture was shampooed. Rented scaffolding was brought in for painting the upper walls of the atrium-like reading room. By April 27, Acquisitions and Cataloging were moving back in to their original space on the second floor.

Here we began to see the benefits of the disaster. Most obvious were the results of the cleanup: new carpeting and painting, newly cleaned furniture, and dust-free books for the first time in almost thirty years. In the Reference, Cataloging, and Acquisitions areas, where the drop ceiling was replaced to allow for encapsulation of the asbestos-containing insulation, new and improved recessed lighting was installed. Through- 
out the second floor, the fact that every piece of furniture had been removed made it easy for us to imagine reconfiguring the space, and we took advantage of the opportunity. Ethernet wall ports were moved and installed in more convenient spots; desks, shelves, and file cabinets were relocated to improve the workflow and make better use of space. The Reference Desk, which had for years extended out into the open atrium area of the second floor, was moved back under the third floor mezzanine overhang to reduce the noise level and create a more open and inviting entrance space. Public catalog workstations that had been clustered around the central staircase in a haphazard way were moved into a much more streamlined and efficient configuration.

Finally, on Monday, May 2, the Law Library reopened fully, in time for the last week of classes. The occasion was marked with a Welcome Back party, complete with balloons, coffee, pastries, and cake.

Probably the greatest benefit from the disaster was an intangible one. As Maurice B. Line comments, "coping with [library disasters] can bring out in staff a sense of community that surprises them: it is a sort of extreme team-building adventure course."14 In our case, the disaster brought out the best in everyone. Staff members worked long and hard without complaint, and displayed unsuspected talents. The result was a new level of mutual respect and teamwork. Moreover, "[d]isasters of this kind are also good publicity, and can evoke in the community a great feeling of support and sympathy." 15 By doing everything we could to continue to provide services to our students-and by making sure they knew what we were doing-we sustained our already good relationship with the students, and, I suspect, even improved in their estimation. We were very gratified when the UB Law School Student Bar Association awarded the Law Library Staff a special Certificate of Appreciation "for outstanding service to the Law School and the student body in the aftermath of the fire." While we hope we never have to go through a similar experience again, it is undeniable that we came through stronger and better than before.

\section{ENDNOTES}

1. University at Buffalo Libraries Disaster Prevention, Response, and Recovery Manual (Dec. 26, 2002), http://ublib.buffalo.edu/libraries/units/cts/preservation/manual. html.

2. United States Environmental Protection Agency, What Is Asbestos? (October 20, 2004), http://www.epa.gov/region6/6pd/asbestos/asbestos.htm. 
3. These figures suggest that the collections held by the Law Library are more important to other university programs than is often recognized. This has several implications for us. As one of the handful of non-autonomous U.S. law school libraries, our budget is a fixed percentage of the University Libraries budget. The usage data we uncovered here tends to confirm our argument that adequate financial support for the Law Library benefits the entire University, not just the law school. It also tends to support our policy decision that the Law Library should be open to the entire University community, and that (except during exam periods) access should not be limited to law students.

4. "CafePress.com is an online marketplace that offers sellers complete e-commerce services to independently create and sell a wide variety of products, and offers buyers unique merchandise across virtually every topic. Launched in 1999, CafePress. com has empowered individuals, organizations and businesses to create, buy and sell customized merchandise online using the company's unique print-on-demand and e-commerce services. Today, CafePress.com is a growing network of over 2 million members who have unleashed their creativity to transform their artwork and ideas into unique gifts and new revenue streams." CafePress.com, http://www.cafepress.com/ ublawlib (last visited July 5, 2005).

5. This service is provided by the staff of the Acquisitions Department, who received training from the U.S. Department of State's Bureau of Consular Affairs, Office of Passport Services/Customer Service in Boston. Applicants for a passport under this program pay a $\$ 30$ fee to the Passport Acceptance Facility in addition to the standard application fee.

6. A blog (short for "weblog") is a simple tool that allows a "blogger," or author, to add to a web page frequently and easily, with the most recent additions at the top of the page. A blog at its simplest consists of hypertext links with comments, arranged in reverse chronological order.

7. Meg Hourihan, What We're Doing When We Blog (June 13, 2002), http:// www.oreillynet.com/pub/a/javascript/2002/06/13/megnut.html (describing common features of blogs); Rebecca Blood, Weblogs: A History and Perspective (Sept. 7, 2000), http://www.rebeccablood.net/essays/weblog_history.html (describing functions of blogs).

8. The first posting simply announced, "This is the UB Law Library in Exile. Watch this space for news and updates about the University at Buffalo Law Library services during recovery from the weekend fire." UB Law Library in Exile, http:// ublawlib.blogspot.com/2005/03/this-is-ub-law-library-in-exile.html (last visited July 5, 2005).

9. Naomi Lederer \& Douglas J. Ernest, Managing the Media During a Library Crisis, AMERICAN LIBRARIES, December 2002, at 32.

10. Law Library staff assist users with research and basic computer questions such as how to save documents on their network servers, as well as making sure that the printers are supplied with paper and toner, and clearing print jams. Law IT is responsible for maintaining the computers and administering the servers.

11. This was not the only surprise for the students. Several law students asked at the Lockwood Library Circulation Desk to check out study carrels, only to learn that the Law Library was the only library on campus with locking study carrels.

12. The third floor also holds the regional reporters, state materials, and law journals. Primary federal and New York materials are located on the second floor. This area, the most seriously affected by the smoke, remained off limits during cleaning and 
restoration. While these are the Law Library's core materials, they were also the most readily duplicated online.

13. James Milles, "Rename the Blog" Contest (April 13, 2005), http://ublawlib. blogspot.com/2005/04/rename-blog-contest.html.

14. Maurice B. Line, Management Musings 9: Extracting Pearls from Rotten Oysters, 23 LIB. MGMT. 435, 436 (2002).

15. Id.

Received: $08 / 25 / 05$

Revised and Accepted: 08/16/05

\section{APPENDIX. Selected Resources on Disaster Preparedness}

The literature on disaster preparedness in libraries is voluminous, and much of it suffers simultaneously from too little and too much detail. An initial instruction on developing a plan, "Win the support of your supervisors," cries out for specific suggestions on how to convince supervisors to devote resources to the effort. On the other hand, the attempted comprehensiveness of some of the proposed plans is daunting, and better guidance on how to prioritize the elements of a disaster plan would be desirable. Given limited resources, a particular institution may need to focus its efforts on those elements of a plan that enable the quickest response, or that would have the greatest impact. Should a library focus on the types of disasters most likely to occur, or on those that, while unlikely, would have the greatest cost? Hesitancy to undertake such an intimidating task as some of the literature suggests is essential might prevent some institutions from even starting to prepare. Libraries contemplating a disaster preparedness plan should recognize that a partial plan is better than none. As my undergraduate English advisor, the late Walter J. Ong, S.J., once said in class (to illustrate how the folk wisdom in clichés can often be inverted and remain true), "anything worth doing is worth doing poorly."

Camila A. Alire, The Silver Lining: Recovering from the Shambles of a Disaster, 38 J. LIB. ADMIN. 101-107 (2003).

Perhaps it takes surviving a truly large-scale disaster like the flood that destroyed much of the Colorado State University's Morgan Library in 1997 (see LIBRARY DISASTER PLANNING AND RECOVERY HANDBOOK, below) to see the benefits. Here, writing some years after the fact, the Director of the Morgan Library reflects on some of the unforeseen benefits of the experience. 
Christopher Anglim, Survey on Emergency Preparedness Planning (AALL Publication Series No. 56, Briefs in Law Librarianship Series Vol. 3, 2000).

The author sent a detailed survey to 174 United States law libraries to measure the level of emergency preparedness readiness in the nation's law libraries. Libraries surveyed were chosen from the AALL Directory for 1997; it does not appear that the author made any attempt at a random sample. Sixty-three questionnaires were returned, for a response level of $36.2 \%$. $44.5 \%$ of respondents had a written disaster plan in place. The bulk of the report consists of advice on necessary elements of the development and implementation of a disaster preparedness plan, interspersed with survey figures indicating what percentage of libraries had met the specified criteria. Also included are a four-page bibliography and sample worksheets, procedures, and plans.

Christopher Anglim, The Worst Thing That Could Happen! Law Library Disasters and Preparing for the Unimaginable, AALL SPECTRUM, December 1996, at 8-19.

A good general overview of the elements of a comprehensive disaster preparedness plan, addressing a wide variety of types of disasters, including computer emergencies, explosions, fire, hazardous materials, medical emergency, natural disasters, power failures, shelving or structural collapse, and water damage or flooding.

Sally A. Buchanan, Preservation Management: Emergency Preparedness, in PRESERVATION: ISSUES AND PLANNING (Paul N. Banks \& Roberta Pilette, eds., Chicago, American Lib. Assn. 2000).

Describes a process for disaster planning as part of an overall library plan of preservation management.

Conservation OnLine, http://palimpsest.stanford.edu (last visited July 10, 2005).

"CoOL, a project of the Preservation Department of Stanford University Libraries, is a full text library of conservation information, covering a wide spectrum of topics of interest to those involved with the conservation of library, archives, and museum materials." Includes an online manual, DISASTER PREPAREDNESS AND RESPONSE, http://palimpsest. stanford.edu/bytopic/disasters/ (last visited July 10, 2005). 


\section{APPENDIX (continued)}

Susan S. DiMattia, Planning for Continuity, LIB. J., November 15, 2001, at 32-34.

The terrorist attacks of September 11, 2001 gave rise to a subset of literature on libraries and disaster response. This article, published two months after the event, describes how some affected libraries were coping.

Genovese, Robert, Disaster Preparedness Manual, http://www.law.arizona. edu/library/disastermanual/ (last visited October 4, 2005).

A comprehensive manual prepared for the University of Arizona College of Law Library, this has been published in five print editions $(1989,1993$, 1995, 1998, and 2003) by William S. Hein \& Co. An excellent example for all law school libraries.

Higginbotham, Barbara Buckner, Managing Emergencies: Small Construction Projects, TECHNICALITIES, October 1996, at 1, 12-14.

A routine expansion and remodeling project went wrong, resulting in a coating of concrete dusk contaminating the entire building. Lesson learned: nothing is routine.

Robert Howes, After the Disaster: Drawing Up the Insurance Claim, 5 ASLIB PROC. 181-187 (2003).

Gives advice on insuring library collections and filing insurance claims after disasters. Stresses the importance of keeping accurate records and statistics.

LIBRARY DISASTER PLANNING AND RECOVERY HANDBOOK (Camila Alire, ed., New York, Neal-Schuman Publishers 2000).

At over 600 pages, a comprehensive and detailed guide developed by the staff of the Colorado State University Library based on what they learned from dealing with a devastating flood that destroyed half the Library's collection in 1997. Each chapter includes a one-page bulleted list of "Key Recommendations." This is an essential resource for all libraries.

Miriam B. Kahn, DISASTER RESPONSE AND PLANNING FOR LIBRARIES (Chicago, American Lib. Assn. 1998).

A general manual on disaster response and planning, especially useful as a resource guide to recovery procedures for different types of materials. 
Naomi Lederer \& Douglas J. Ernest, Managing the Media During a Library Crisis, AM. LIB., December 2002, at 32-33.

Another take on the Colorado State University Library flood. News media tend to misrepresent disasters. Disaster plans should include procedures for responding to the media, with a designated spokesperson who can be credible and at ease with the press.

Adrienne Muir \& Sarah Shenton, If the Worst Happens: The Use and Effectiveness of Disaster Plans in Libraries and Archives, 23 LIB MGMT. 115-123 (2002).

An analysis of the development and use of disaster plans based on six case studies of UK libraries and archives. Contact lists proved to be the most useful part of the plan for disaster response. Common problems include: inaccurate contact lists; failures of other departments; lack of planned process to record items sent for freezing; inadequacy of disaster supplies; and problems following health and safety guidelines.

Northeast Document Conservation Center, 100 Brickstone Square, Andover, MA 01810-1494, tel. (978) 470-1010, http://www.nedcc.org.

An essential resource for any library developing a disaster preparedness plan-or finding themselves suddenly without one. NEDCC is "the largest nonprofit, regional conservation center in the United States. Its mission is to improve the preservation programs of libraries, archives, museums, and other historical and cultural organizations; to provide the highest quality services to institutions that cannot afford in-house conservation facilities or that require specialized expertise; and to provide leadership to the preservation field." NEDCC provides a variety of conservation services on a for-fee basis, but their experts kindly provided us, without charge, with advice on cleaning our collection of rare books.

Julie Todaro, Managing Through Tragedy, 16 LIB. ADMIN. \& MGMT. 40-43 (2002).

Another response to the 9/11 disaster. This article stresses the human aspects of tragedy response, including evacuation plans and staff support issues ranging from routine management to mental health issues. 